\title{
The Urgency of Adversity Quotient for Women Running the Small Businesses
}

\author{
Mar'atus Sholikhah \\ Department of Psychology, Faculty of Psychology and Social Cultural Sciences, Islamic University \\ of Indonesia, Yogyakarta
}

\section{Faraz}

Master of Professional Psychology, Faculty of Psychology and Social Cultural Sciences, Islamic University of Indonesia, Yogyakarta

Abstract. During the economic crisis occurring in Indonesian, entrepreneurial sector has been the solution for Indonesian economic downturn. However, entrepreneur women face more specific obstacles which complicate their steps, then it causes the fact that there are more entrepreneur women have contributions in Indonesian economic growth (60\%) is less exposed (Tjahjadi et al, 2019). The study is aimed to identify the relationship between adversity quotients with entrepreneurial intentions of entrepreneur women. The hypothesis proposed in this study is that there is a positive relationship between adversity quotients with entrepreneurial intentions of entrepreneur women. The research subjects were 100 batik entrepreneur women. The scale used in this study was made based on the aspects of the Theory Planned Behavior (TPB) by Ajzen for the entrepreneurial intention variable and aspects of the Adversity Response Profile (ARP) by Stotlz for the adversity quotient variable. The hypothesis test result using Pearson's productmoment showed a correlation number $r$ of .497 and $p=.000(p<.01)$. It indicates that there is a significant relationship between Adversity Quotient and Entrepreneurial Intensity so that the proposed hypothesis is accepted. The implication of the research is for encouraging the entrepreneur women to create solution to overcome adversities in developing the business.

Keywords: adversity quotient, entrepreneurial intention, entrepreneur women

\section{Urgensi Adversity Quotient bagi Perempuan Pelaku Usaha Kecil}

Abstrak. Selama krisis ekonomi berlangsung di Indonesia, wirausaha dapat menjadi penyelamat ekonomi bangsa hingga dapat bangkit kembali. Namun wirausahawan wanita memiliki banyak hambatan khusus yang menyulitkan mereka, sehingga fakta bahwa wirausaha perempuan berkontribusi lebih banyak (60\%) dalam pertumbuhan ekonomi menjadi tertutupi (Tjahjadi et al, 2019). Penelitian ini bertujuan untuk mengetahui hubungan antara adversity quotient dengan intensi berwirausaha pada perempuan pengusaha. Hipotesis yang diajukan dalam penelitian ini adalah ada hubungan positif antara adversity quotient dengan intensi berwirausaha pada perempuan pengusaha. Subjek penelitian 100 orang perempuan pengusaha batik. Skala yang digunakan dalam penelitian ini dibuat berdasarkan aspek dari Theory Planned Behavior (TPB) oleh Ajzen untuk variabel intensi berwirausaha dan aspek dari Adversity Response Profile (ARP) oleh Stotlz untuk variabel adversity quotient. Hasil uji hipotesis menggunakan product moment dari Pearson menunjukkan angka korelasi r sebesar.497 dan $p=.000(p<.05)$. Hal ini menunjukkan bahwa terdapat hubungan yang signifikan antara Adversity Quotient dengan Intensitas Berwirausaha. Implikasi dari penelitian ini adalah untuk mendorong wirausahawan wanita untuk menemukan solusi dalam menghadapi hambatan yang dihadapi selama mengembangkan bisnisnya.

Kata Kunci: adversity quotient, intensi berwirausaha, perempuan wirausaha

Korespondensi: Faraz. Email: 159151301@uii.ac.id 
Entrepreneurship is an interesting topic in the national economic arena because entrepreneurial actors (MSMEs) contribute $99.99 \%$ of all existing businesses, employ $89 \%$ of the private sector workforces, and contribute 57\% to GDP (Japhta et al., 2016). The number of MSMEs and also the expanding MSME employment are the main drivers for reducing poverty and increasing income (Putra, 2016). Its role during the economic crisis has made many parties realize that entrepreneurship is potential of being the saviour of Indonesia's economic downturn. Until the crisis ends, entrepreneurship remains the cornerstone of the government in encouraging Indonesia's economic growth (Tjahjadi et al., 2019). However, there is not enough exposure to how entrepreneur women are the ones who contributes more $(60 \%)$ in the growth of Indonesian economical state

The 2016 World Bank survey stated that $52.9 \%$ of micro-enterprises, $50.6 \%$ of small businesses, and $34.0 \%$ of medium-sized enterprises in urban areas were owned by women (Azizah, 2019). Although the majority (85\%) of businesses managed by women are micro and small enterprises, the impact is very large (Azizah, 2019). Entrepreneur women in Indonesia have employed not less than 15 million employees; it means that we can call them as agents of change because they can be the source of economic activities by creating job fields. Another advantage is that entrepreneur women have higher life forces compared to entrepreneur men. Today's entrepreneurial women enlarge the skills by developing businesses which are normally managed by men, such as factory management, construction, transportation, and agriculture (Armiati, 2015). Based on a BPS survey (2018), the number of female SME entrepreneurs has reached 14.3 million people, where the number increased up to 1.6 million people from 12.7 million people the previous year. Finally, entrepreneur women are listed as bank borrowers with a lower default rate than men (Tjahjadi et al, 2019).

Women running the micro and small businesses are also considered as having several weaknesses, they are: (a) the attitude of less assertive and lack of confidence can be the obstacles for risk-taking; (b) the status in the social structure make women to be dependent on men (family); (c) women have less access to education and training; and (d) the difficult access for loans and credit for women (Tambunan, 2017). These constraints become the basis for Indonesia women in choosing business fields (Saputri \& Himam, 2015). In addition to these basic weaknesses, entrepreneur women are faced with situations that hinder or make it difficult for them to build a successful business. For entrepreneurial women, therefore, they must fully understand the issues related to the income uncertainty, the risk of losing all investment, and the responsibility (Smith \& Chimucheka, 2014). 
In connection with the many obstacles faced by entrepreneur women, the existence of entrepreneurial intentions is often becoming a solution for the entrepreneur women. According to Choo \& Wong (2006) intention is proven to be a predictor for entrepreneurial behaviour, or in other word, intention can support the business success. A preliminary study conducted by researchers by interviewing two entrepreneur women who clothing stores in Sleman district (on July 2018) found that the married women who wanted to increase the family income had higher interest in entrepreneurship. However, not all of them can run the business well since there are many factors affect it, including the factor of intention in doing entrepreneurship.

The intention based on the Theory of Planned Behavior is assumed that humans are rational creatures, they think about the implications of actions before deciding to do or not to do certain behaviors. Individual behavior is guided by three things, they are behavioral beliefs, normative beliefs, and control beliefs. Behavioral beliefs are a person's beliefs about the expected outcome of the behavior and evaluation of these outcomes. Normative beliefs are normative expectations regarding behavior and motivation to fulfill these expectations. Control beliefs are individual beliefs about factors that can inhibit behavior and the ability to overcome these factors (Fishbein \& Ajzen, 2005).
Entrepreneurial intention is defined as the tendency of an individual to take entrepreneurial action by creating a new product through business opportunities and taking risks (Ramayah \& Harun, 2005). According to Hattab (2014), entrepreneurial intention can be defined as a state of mind that directs and guides each individual towards the development and implementation of new business concepts. The intention has been proven to be the best predictor of entrepreneurial behavior, intention in entrepreneurial behavior can support the business success, and it maintains activeness in doing entrepreneurship. An intention is a basic approach that enables us to identify which person will be an entrepreneur (Choo \& Wong, 2006). In this case, the intention of entrepreneurship is also defined as the desire that exists within the individual to create a business which can provide employment both for himself and for others with the provision of independence, courage, and creativity. The entrepreneurial intentionof a person will get weaker due to a lack of confidence, doubt, and fear of failure then it leads the person not to be ready to face the obstacles/difficulties existing in the entrepreneurship. Thus only people who can survive and overcome obstacles are having strong entrepreneurial intentions. The ability to survive and overcome obstacles or difficulties by Stoltz (2007) is called the adversity quotient or level of resistance to pressure. 
The results of the researchers' interview with two respondents in Godean sub-district, Sleman district, showed that they had problems with their intention in entrepreneurship. Mrs. Reisa, the owner of a fashion shop, mentioned that at the beginning of running her business, there were many other shops as competitors. It created pessimistic in her mind because of the lack of product marketing. She started the business as a reseller. However, equipped with a strong belief, she finally could open her own boutique (Interview result on July 13, 2018). Rahma, a homemade hijab entrepreneur, explained that she is always passionate to entrepreneurship and is eager to have her best creations. Then she spent her time running a business while in the same time she can take care her family. Rahma stated that the biggest challenge in having a business is finding the customers. Complains from customer for their dissatisfaction of the product sometimes occur. Rahma said that the initial intention of entrepreneurship was to help the family financial and her business was a home business which did not bother her role as a mother and a wife to take care the domestic chores (Results of the interview, 14 July 2018).

Research Srimulyani (2013) mentioned that there are factors that affect the level of intention, namely the level of resistance to pressure or adversity quotient. His research found that the three factors influencing intention are personality characteristics (such as risk-taking, creativity, and innovation), Locus of control, and various intelligence indicators (intelligence -, emotional , the spiritual -, and adversity quotient).

Research Stoltz (2007) stated that intelligence in facing the adversity (adversity quotient) has three forms. The first one is the adversity quotient as a new conceptual framework for understanding and improving all aspects of success. The second one is the adversity quotient as a measure to determine an individual's response to difficulty. The third one is the adversity quotient as an instrument that has a scientific basis for improving one's response to adversity. The adversity quotient in this study is understood to see the extent of a person's ability to handle various kinds of difficulties, to find solutions and how to exploit their potential in overcoming these difficulties.

Declared there is a strong relationship between adversity quotient and entrepreneurship (Kline et al., 2004). He explains in his study that a person with a higher adversity quotient can take higher risks, have more control, have the perseverance and confidence to continue the business, easier to find new ideas, strategies, and also products to compete in resulting in increased profits and higher income. Adversity Quotient can be useful for predicting performance, motivation, empowerment, creativity, productivity, learning, expectation, resilience, and response to change (Phoolka \& Kaur, 2012).

Research Surekha (2001) added that adversity quotient is the ability to think, to manage, and to have direct actions which form 
a pattern of cognitive and behavioral responses toward the stimuli of events in life in the form of challenges or difficulties. Adversity Quotient on entrepreneurship is a description of how far an entrepreneur's performance in facing challenges and solving problems in developing a business. These challenges can be in the form of financial, emotional, physical, social, and related to their career development as an entrepreneur. Without a high Adversity Quotient, it is feared that an entrepreneur will experience frustration and dificulties in going through the process of becoming an entrepreneur (Stoltz, 2007). Otherwise, Stoltz (2007) stated that the concept of Adversity Quotient is related to entrepreneurial success because running an entrepreneurial business requires courage to face failure, and the willingness to try continuously until it is successful. Adversity Quotient is useful for increasing the effectiveness within the scope of team, work relationship, family, company, association, culture, and society. Adversity Quotient will act as a prediction of a person's success or failure. This is very necessary for an entrepreneur to be able to face all problems or obstacles that are experienced during running a business.

Adversity Quotient indicates that resilience is a major factor that determines the success in entrepreneurship. Successful entrepreneurs have significantly higher Adversity Quotient level than those who are less successful. Resilience has been argued as an appropriate measure of entrepreneurial success in the early stages of the venture when financial indicators are difficult to identify, unavailable, or inappropriate (Stoltz, 2007).

For entrepreneur women, the adversity quotient is needed to be able to face all the problems or obstacles they experience while running a business. A research conducted by Dhanita \& Hidayat (2015) on culinary entrepreneurship also indicated that the adversity quotient is needed by culinary entrepreneurs to overcome the occurring problems. A study held by Ekasari \& Hafizhoh (2009) also found that there is a positive relationship with the weak correlation category between adversity quotient and intention. Based on the explanation above, the researcher is interested in and considers that the research on adversity quotient toward entrepreneurial intentions is important to further clarify how big the impact of the adversity quotient on entrepreneurial intentions by having female entrepreneurs as the research subjects. This research was conducted door-to-door by seeing the subject directly to eliminate the unwanted variables and this process was different than all the previous research methods mentioned above. The hypothesis in this study is there is a positive relationship between adversity quotient and entrepreneurial intentions.

\section{Method}

\section{Subject}

In this study, the subjects were 120 entrepreneur women as the members of the 
Manunggal Batik Association in Sleman Regency, Yogyakarta.

\section{Research Instruments}

The data collection method used in this study used the scale method. A scale is a measuring tool that contains questions to reveal the psychological attributes to be measured indirectly (Azwar, 2012). This research used a Likert scale. The Likert scale consists of statements or items to measure certain psychological attributes (Supratiknya, 2015). Subjects were asked to state their agreement and disagreement in a continuum consisting of five responses: Strongly Agree (SS), Agree (S), Slightly Disagree (KS), Disagree (TS), and Strongly Disagree (STS). The scales used in this study were a scale of entrepreneurial intentions and the adversity quotient.

\section{Entrepreneurial Intention Scale}

This scale was used to reveal the intention of entrepreneur women in entrepreneurship. The entrepreneurial intentions instrument was developed based on Ajzen's Theory of Planned Behavior (1991) and compiled by researchers through three aspects, namely behavioral beliefs, normative beliefs, and behavior control. The scale arrangement was grouped into favourable and unfavourable items. There were several items on the scale about entrepreneurial intention. There were 35 items available and it consisted of 17 favourable statements and also 18 unfavourable statements. Researchers used the Likert scales where the favourable assessment ranged from 1 (one) to 5 (five) with options on a scale starting from "strongly agree" which had a value of 5, "agree" which had a value of 4, "slightly agree" which had a value of 3 , "disagree" which had a value of 2 , "strongly disagree" which had a value of 1 . The unfavourable scales started from "strongly agree" which had a value of 1 , "agree" which had a value of 2 , "slightly disagree" which had a value of 3, "disagree" which had a value of 4 , "strongly disagrees" which had a value of 5 . Therefore, the individual maximum score on this scale was 175 and the individual minimum score on this scale was 35.

\section{Adversity Quotient Scale}

This scale was used to reveal the adversity quotient of entrepreneurial women in entrepreneurship. The adversity quotient instrument used in this study was prepared by the researcher by concerning to the theory of Stoltz (2007) which consists of four dimensions, those are: Control, Origin \& Owners, Reach, and Endurance. The scale arrangement was grouped into favorable and unfavorable items. The number of items on the Adversity Quotient scale was 36 items. There were 21 favourable items in total and 15 unfavourable items in total. Researchers used the Likert scale where the favorable assessment ranged from 1 (one) to 5 (five) with alternative answers on a scale starting from "strongly agree" which had a value of 5, "agree" which 
had a value of 4, "slightly agree" which had a value of 3 , "disagree" which had a value of 2 , "strongly disagree" which has a value of 1 . The unfavorable scales started from "strongly agree" which had a value of 1, "agree" which had a value of 2 , "slightly disagree" which had a value of 3 , "disagree" which has a value of 4 , "strongly disagrees" which has a value of 5 . Therefore, the individual maximum score on this scale was 180 and the individual minimum score on this scale was 36.

\section{Data analysis}

The data analysis technique used in this study was Pearson's product moment analysis.
This analysis technique was used because the research data was normally distributed. In addition, as an additional analysis, the researcher also conducted an analysis based on demographics, age and length of work. Data analysis was performed using SPSS version 21 software.

\section{Results}

The result of the assumption test shows that the data distribution meets the normality requirements, namely $p$ which has value greater than .05 , and the result of the linearity test shows the two linear variables.

\section{Table 1}

Description of research data

\begin{tabular}{lc}
\hline \multicolumn{1}{c}{ Variables } & $P$ \\
\hline Entrepreneurial Intentions & $.538^{*}$ \\
Adversity Quotient & $.235^{*}$ \\
\hline Note. $^{*} p>.05$ &
\end{tabular}

Table 2

Normality Test Result

\begin{tabular}{lcccc}
\hline \multirow{2}{*}{ Variables } & \multicolumn{4}{c}{ Hypothetical } \\
\cline { 2 - 5 } & Max & Min & M & SD \\
\hline Entrepreneurial Intentions & 128.00 & 75.00 & 112.11 & 8.066 \\
Adversity Quotient & 136.00 & 91.00 & 122.21 & 7.511 \\
\hline
\end{tabular}

Based on the table, it is shown that both variables are normally distributed. Therefore, researcher used Pearson's correlation as a parametric test for hypothesis' testing. 


\section{Table 3}

Hypothesis Test Result

\begin{tabular}{lcc}
\hline \multicolumn{1}{c}{ Variables } & $r$ & $p$ \\
\hline Adversity Quotient with & .551 & $.000^{*}$ \\
Entrepreneurial Intentions & &
\end{tabular}

Note. ${ }^{*} p<.05$

The result of the analysis shows that the correlation coefficient $r=.551$ with $p=$ $.000(p<.05)$. This indicates that there is a positive relationship between the adversity quotient and entrepreneurial intentions of the entrepreneur women. Additional analysis results can be seen in the following table.

\section{Table 4}

The Result of Different Test of Adversity Quotient and Entrepreneurial Intention based on Age

\begin{tabular}{lccc}
\hline \multicolumn{1}{c}{ Variables } & \multicolumn{2}{c}{$\mathrm{M}$} & $p$ \\
\cline { 2 - 3 } & $<45$ years & $\geq 45$ years & \\
\hline Adversity Quotient & 121 & 122.9 & $.761^{*}$ \\
Entrepreneurial & 111.68 & 112.35 & $.590^{*}$ \\
Intentions & & & \\
\hline
\end{tabular}

Note. ${ }^{*} p>.05$

In the result of different test based on age between subjects aged less than 45 years and demonstrates that there was no difference more than or equal to 45 years.

\section{Table 5}

Test Result for Difference in Adversity Quotient and Entrepreneurial Intention Based on Length of Business

\begin{tabular}{lccc}
\hline \multicolumn{1}{c}{ Variable } & \multicolumn{2}{c}{$\mathrm{M}$} & $p$ \\
\cline { 2 - 3 } & $<3$ years & $\geq 3$ years & \\
\hline Adversity Quotient & 121.97 & 122.84 & $.358^{*}$ \\
Entrepreneurial & 112.42 & 111.25 & $.359^{*}$ \\
Intentions & & & \\
\hline Note. ${ }^{*} p>.05$ & & &
\end{tabular}


In the result of different test based on length of business, there was no difference between subjects who had run a business for less than 3 years and for those who did more than or equal to 3 years.

\section{Discussion}

The purpose of this study is to determine the relationship between adversity quotient and entrepreneurial intentions. The results of the study indicate that there is empirical support for the relationship between the two variables. This means that the level of entrepreneurial intentions of entrepreneur women can be explained by the adversity quotient variable. The results of the R coefficient analysis are .551, $p=.00(p<.01)$, and the value (Adjusted R Square) is .303. It shows that there is a positive and significant relationship with the moderate category between adversity quotient and entrepreneurial intentions. The higher the adversity quotient for entrepreneur women, the higher the entrepreneurial intention will be. The results of this study are in line with the research of Budiono (2013) and Srimulyani (2013) which state that there are factors that influence high and low intentions, namely the level of resistance to pressure or adversity quotient. Research by Alifiah et al (2018) regarding the relationship between adversity quotient and entrepreneurial intentions in cooperative members and management also shows the same results. It is also in accordance with the study conducted by Kurniawati and
Marlena (2018) regarding the relationship between adversity quotient and entrepreneurial intentions in vocational classes at State Vocational High Schools.

The researchers analysed to determine the effective contribution or strength in the research about the adversity quotient variable toward entrepreneurial intentions. Based on the measurement results, the adversity quotient variable contributed $30.3 \%$ to the entrepreneurial intention. There were $69.7 \%$ of other variables that affect the entrepreneurial intention variable. The results of this study are in line with the results of a research conducted by Zahreni \& Pane (2012) that the adversity quotient affects the intention to be an entrepreneur and it contributes .097 (9.7\%). A research conducted by (Rahayuningsih, 2017) states that the adversity quotient affects the intention to become an entrepreneur and it contributes .19 (19\%). Based on the calculation of the effective contribution, many other factors will influence entrepreneurial intentions such as family environment, entrepreneurship education, entrepreneurial competence, self-efficacy, and courage to take the risks. Compared to the two studies, this study has a higher result with the contribution of $30.3 \%$. It may be due to the different data collection processes. This research was conducted door-to-door by meeting the subject directly, and the researchers were able to explain if there were questions that were not understandable. 
Meanwhile, researches by Zahreni \& Pane (2012) and Rahayuningsih (2017), they only distributed questionnaires in the process of data collection and could not confirm whether the filling process was carried out correctly or not.

The results of the additional analysis regarding the correlation between entrepreneurial intentions and adversity quotient for entrepreneur women based on age show that the strength of the relationship between entrepreneurial intention and adversity quotient according to the age group $<45$ years and the age group e" 45 years can be seen in table 3 . Entrepreneur women at ages e" 45 years need more help in increasing entrepreneurial intentions to maximize adversity quotient compared to the entrepreneur women $<45$ years. Based on the length of time in starting a business, the relationship between the adversity quotient and entrepreneurial intentions can be seen in table 3 , that entrepreneur women who have businesses ( $<3$ years) are more likely to need an increase in the adversity quotient.

The implication of this research is to encourage entrepreneur woman to create solution to overcome adversities in the business. This study has several limitations, namely the scale of the research made by researchers is less than perfect and there are still many shortcomings. Some statements on the adversity quotient dimension are real and should be perceptual.

\section{Conclusion}

Based on the results of the analysis that has been carried out from this study, it can be concluded that there is a significant relationship between the adversity quotient and entrepreneurial intentions. The results of the correlation analysis indicate that there is a significant positive relationship between the adversity quotient and entrepreneurial intentions. This means that the adversity quotient is needed and very urgent for entrepreneur women who run the micro, small, and medium enterprises. For further research on entrepreneurial intention, it is better to involve other variables such as self-efficacy or personality.

\section{Suggestion}

Thus, it is highly recommended to the government and stakeholders to provide empowerment in the form of training or education related to the method of increasing the adversity quotient for women doing MSMEs, so that their contribution to regional and national economic growth can be further enhanced. Also, for further researches, it is expected that they can expand the population, or add other variables so that the findings are more varied so that the conclusions obtained are more comprehensive.

\section{References}

Alifiah, Murwani, F. D., \& Wardana, L. W. (2018). Influence of adversity quotient and entrepreneurial self efficacy to the entrepreneurial intention on 
management and members of cooperative. European Journal of Business and Management, 10(13).

Armiati. (2015). Women entrepreneurs serta faktor-faktor yang mempengaruhinya (Kasus pada pengrajin Sulaman wanita di Jorong Lundang Kanagarian Panampuang Kab. Agam). Economica, 1(2), 162-174. https://doi.org/ 10.22202/economica.2013.v1.i2.116

Azizah, S. N. (2019). Wanita dan peranannya dalam memajukan UMKM batik di Kebumen. Jurnal Ilmiah Bisnis Dan Ekonomi Asia, 13(1), 15-19. https:// doi.org/10.32812/jibeka.v13i1.98

BPS. (2018). Statistik e-commerce 2018. Badan Pusat Statistik. Badan Pusat Statistik

Budiono, I. L. (2013). Hubungan antara adversity quotient dengan intensi berwirausaha pada mahasiswa program mahasiswa wirausaha Universitas Negeri Surabaya. Jurnal Psikologi Pendidikan, 4(3), 1-6.

Choo, S., \& Wong, M. (2006). Entrepreneurial intention: Triggers and barriers to new venture creations in Singapore. Singapore Management Review, 28.

Dhanita, L., \& Hidayat, A. (2015). Gambaran adversity quotient pada wirausahawan melayu di bidang kuliner. $A n-N a f s, 9(3)$.

Fishbein, M., \& Ajzen, I. (2005). Belief, attitude, intention, and behavior: An introduction to theory and research. Addison-Wesley Publishing.

Hattab, H. (2014). Impact of entrepreneurship education on entrepreneurial intention of University Students in Egypt. The Journal of Entrepreneurship, 23(1), 1-18.

Japhta, R., Murthy, P., Fahmi, Y., Marina, A., \& Gupta, A. (2016). UKM yang dimiliki wanita di Indonesia: Kesempatan emas untuk institusi keuangan lokal. Laporan Penelitian Kerjasama International Finance Corporation dan USAID. https:// www.ifc.org/wps/wcm/connect/ 8496be45-d4d4-4480a9f549c073294 b26/SME +Indonesia_Final_Ind.pdf?MOD= AJPERES\&CVID=lj8lVuj

Kline, G. H., Stanley, S. M., Markman, H. J., OlmosGallo, P. A., St. Peters, M., Whitton, S. W., \& Prado, L. M. (2004). Timing is everything: Pre-engagement cohabitation and increased risk for poor marital outcomes. Journal of Family Psychology, 18(2), 311-318. https://doi.org/ 10.1037/0893-3200.18.2.311

Kurniawati, W., \& Marlena, N. (2018). The influence of self efficacy and adversity quotient: How is the vocational student entrepreneurial intention? Jurnal Pendidikan Bisnis Dan Manajemen, 4(2), 96-107. https://doi.org/10.17977/ um003v4i22018p096

Phoolka, S., \& Kaur, N. (2012). Adversity quotient: A new Paradigm to explore. International Journal of Contemporary Business Studies, 3(4), 67-78.

Putra, A. H. (2016). Peran UMKM dalam pembangunan dan kesejahteraan masyarakat Kabupaten Blora. Jurnal Analisa Sosiologi, 5(2), 40-52. https:// media.neliti.com/media/publications/ 227635 - peran - u m k m - da la m pe mbangunan-dan-kesejah 7d176a2c.pdf

Rahayuningsih, T. (2017). Perilaku cyberloafing ditinjau dari kecerdasan adversitas dan komitmen kerja. Jurnal Psikologi, 1(1), 49-53.

Ramayah, T., \& Harun, Z. (2005). Entrepreneurial intention among the students of Universiti Sains Malaysia (USM). International Journal of Management and Entrepreneurship, 1, 8-20.

Saputri, R. K., \& Himam, F. (2015). Mindset wanita pengusaha sukses. Jurnal Psikologi, 42(2), 157. https://doi.org/ 10.22146/jpsi.7170

Smith, W., \& Chimucheka, T. (2014). Entrepreneurship, economic growth and 
entrepreneurship theories. Mediterranean Journal of Social Sciences, 5(14), 160-168. https://doi.org/ 10.5901/mjss.2014.v5n14p160

Srimulyani, A. V. (2013). Pengaruh kecerdasan adversitas, internal locus of control dan kematangan karir terhadap intensi berwiraushaa pada mahasiswa bekerja. Jurnal Widya Waria, 1, 96-110.

Stoltz. (2007). Adversity quotient: Mengubah hambatan menjadi peluang. PT. Grasindo.

Surekha. (2001). Adversity intelligence. Pustaka Umum.

Tambunan, T. T. H. (2017). Women entrepreneurs in MSEs in Indonesia: Their motivation and main constraints. International Journal of Gender and Women Studies, 5(1), 88-100. https:// doi.org/https://doi.org/10.15640/ ijgws.v5n1p9

Tjahjadi, A. M., Purwandari, C. A., \& Massie, N. W. . (2019). Recent development of small medium enterprises' businesses profitability: Evidence from Indonesia. Proceedings of the 2nd International Conference on Inclusive Business in the Changing World, 183-189. https:// doi.org/10.5220/0008429001830189

Zahreni, S., \& Pane, R. S. . (2012). Pengaruh adversity quotient terhadap intensi berwirausaha. Jurnal Ekonomi, 15(4), 173-178.

Received 1 February 2021

Revised 22 May 2021

Accepted 31 July 2021 